\title{
Analysis of Optimization Model of Haji Financial Investment Portfolio in BPKH RI (Haji Financial Management Agency of the Republic of Indonesia)
}

\author{
Arif Setyawan $^{1}$, Hendro Wibowo ${ }^{2}$, Mustafa Kamal ${ }^{3}$
}

${ }^{I}$ SEBI: Email: arifsetyawansebi@gmail.com

${ }^{2}$ SEBI Lecturer \& Doctoral Candidate AeU Malaysia Email: hendro.wibowo83@gmail.com ${ }^{3}$ SEBI Lecturer Email: Mustafast@yahoo.com

\begin{abstract}
Financial management board hajj is an institution in which manages investment funds haji who uses the shariah principle in Indonesia. This study aims to analyze the optimization of Indonesian BPKH investment in a period of the year 20172019 in diversified portfolios by adopting both Markowitz. The research data is historical data on investment is being done by BPKH in 2017-2019 which includes instruments, deposits sharia bonds, and a projection on the stocks, and the real sector accommodation. This study used a quantitative approach with the study descriptive. The technique of analysis that was used in this research is the solutions to the results of the portfolio equation optimal with the help of a computer program ms excel solver. The research results show the portfolio BPKH scenario of Indonesia concerning the period of 2017-2019 which showed the level of expected return and 3 on risk scenario investment composition. About the scenario conservative expected return 7,76\% and on the risk $1,09 \%$, scenario moderate expected return $14,70 \%$ and on the risk $3,22 \%$, scenario aggressive expected return $26,62 \%$ and on the risk $6,39 \%$.
\end{abstract}

Keywords: BPKH; Return; Risk Investment; Portfolio Investment; Markowitz.

\section{INTRODUCTION}

Indonesia has the largest hajj pilgrim's quota compared to other countries, but the quota certainly has not been able to accommodate the entire number of Indonesian Muslims who register for hajj. This departs prospective pilgrims to follow the queue schedule for years (Primadhany, 2018). The Indonesian government divides the pilgrimage quota given by the government of the kingdom of Saudi Arabia to the provinces in Indonesia with consideration of the Muslim population in each of these provinces (Salatalohy, 2019). 
Graph 1.1 Number of Indonesian Hajj Departures in 2014-2019

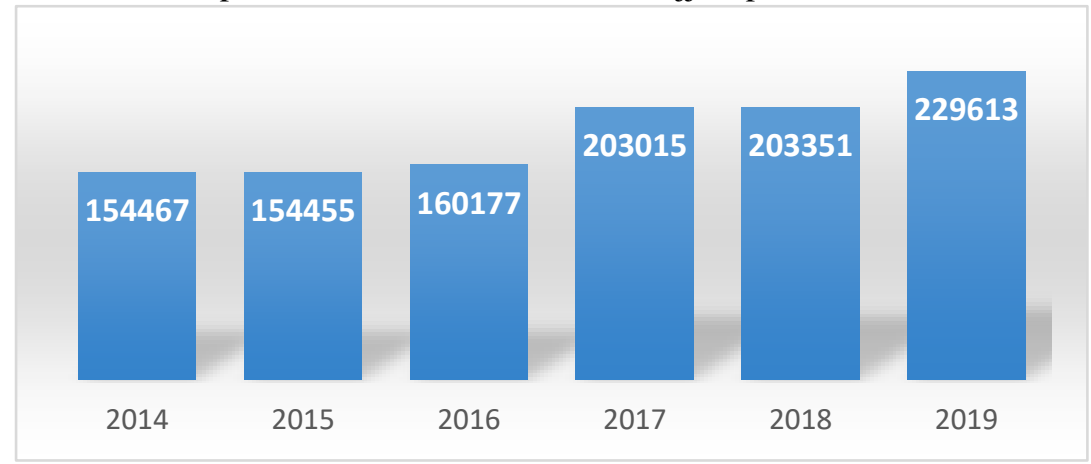

Source: Ministry of Religion (data processed)

In terms of the number of hajj pilgrims, it can be seen from Graph 1.2 that during the span of time between 2014 and 2019, the highest number of hajj pilgrims occurred in 2019 with 229,613 thousand hajj pilgrims. Then, in 2014 the number of pilgrims leaving for the holy land was 154,467 thousand people this year including the current year of Hajj quota pruning which was previously 221,000 people in 2012 then cut by 42,000 people or $19 \%$ until the haj quota became 168,800 inhabitants due to the project to expand the Grand Mosque by the government of Saudi Arabia. In 2015 the number of pilgrims leaving was 154,455 thousand, a decline of 12 pilgrims. In 2016 the number of pilgrims leaving 160,177 people, this number increased by 5722 pilgrims compared to 2015. In 2017 the number of departing 203,015 people, there was a return of the pilgrim quota of 52,000 pilgrims after being pruned in 20132016 because there was an expansion of the Grand Mosque complex from 168,800 quota to 221,000 . In 2018 a total of 203,351 pilgrims departed for the holy land increased by 36 pilgrims again. And in 2019 the total quota of Indonesian pilgrims will increase by 26,262 pilgrims, bringing the total in 2019 to 229,613 Indonesian pilgrims. An increase in the quota for pilgrims does not cover the number of Indonesian hajj registrants so that there remains a buildup resulting in a queue of departures for other pilgrims (Abidin, 2016).

Considering the above conditions, that there was an increase in the number of pilgrims waiting who could result in the accumulation of accumulated hajj funds, the Government of Indonesia issued Law (Law) No. 34 of 2014 concerning Management of Hajj Funds. Through this law, the government established the Hajj Financial Management Board (BPKH) which was officially established in 2017. BPKH is tasked with managing hajj finances which include revenue, development, expenditure, and accountability which are carried out effectively, efficiently, transparently and accountably.

BPIH (Hajj Operation Cost) is divided into two parts based on sources, namely Direct cost \& Indirect Cost. According to his understanding Direct Cost is a cost that is charged to pilgrims to get a seat or quota for the pilgrimage departure. This fee is intended for operations (plane tickets, lodging etc.) pilgrims. Meanwhile, Indirect costs are operational costs of hajj which are 
7 | Arif Setiawan, Hendro Wibowo, Mustafa Kamal : Analysis of Optimization Model of Haji Financial Investment Portofolio in BPKH (Haji Financial Management Agency of the Republic of Indonesia)

not charged to pilgrims and are taken from the value of the benefits of the management of pilgrimage funds saved due to the waiting list (waiting list) of pilgrims.

Graph 1.2 shows the two components of the cost of performing hajj, namely direct costs and indirect costs per hajj pilgrims in 2014-2019 which fluctuated because they were influenced by changes in economic conditions. In 2014 the cost of performing hajj reached Rp 40,225 000 million which then decreased by $\mathrm{Rp} 2,731,000$ million to $\mathrm{Rp} 37,494,000$ in 2015. Then in 2016 the cost of performing hajj decreased by Rp 285,296 to Rp 34,641,304 million In 2017 the cost of hajj will be Rp. 34,890,312 million, an increase of Rp. 249.00 from the previous year. Then in 2018 and 2019 the cost of hajj was determined the same by members of the Indonesian Parliament due to various strategic considerations of Rp. 35,235,602 million.

Graph 1.2. Total Cost of Hajj Pilgrimage Operations per pilgrim 2014-2019

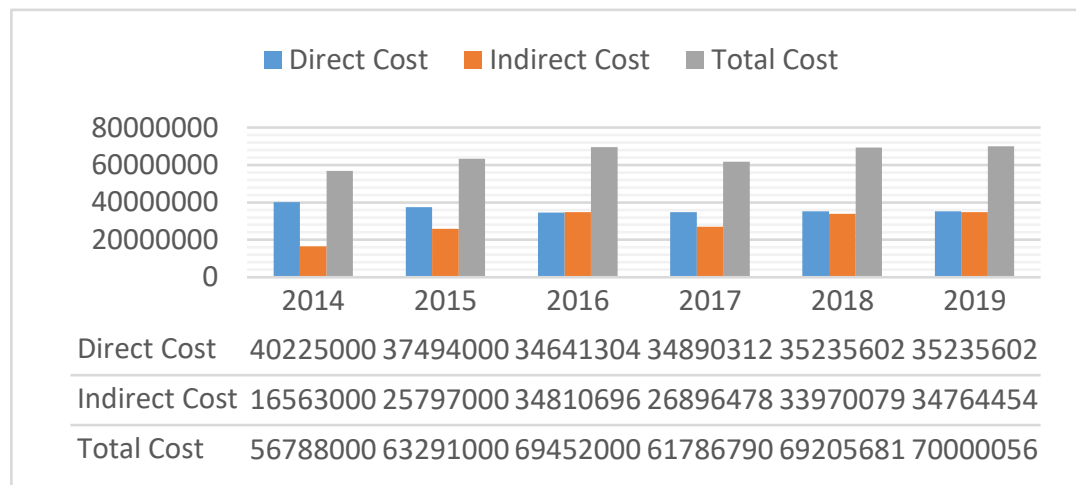

Source: Ministry of Religion (data processed)

Then on the side of the indirect cost of hajj in 2014, the total cost of the hajj was Rp. 16,563,000 an increase of Rp. 9,234,000 so that in 2015 the total cost of Rp. 25,797,000. then in 2016, the number of indirect costs was Rp. 34,810,696 then decreased by Rp. 7,914,218 in 2017 the amount so that the total cost of Rp. 26,896,478. In 2018 the total indirect cost will be Rp. $33,970,079$ and in 2019 the total cost of Rp. 34,764,454 cost trends Indirect costs tend to increase every year.

From 2011 to 2018, the average annual increase in the cost of pilgrimage per pilgrim was $8.17 \%$ (Hidayati, 2018). For the costs of the pilgrimage in 2018-2019, the real cost for direct costs or costs paid directly by pilgrims is $\mathrm{Rp} 35,235,602.00$ while the indirect cost or costs that are not borne by pilgrims is Rp 34,764,454.00 the total becomes Rp. 70,000,050.00 If we look at the amount of indirect cost, it always goes up from time to time and has now equaled the amount of direct cost itself. This is a challenge for BPKH to be able to manage the pilgrimage finances to be able to provide subsidies for 
indirect costs to Indonesian pilgrims so they are not burdened with such a large cost. If we consider between the total Indonesian pilgrims in 2019, which totaled 229,613 pilgrims and the total indirect cost of the pilgrims, which amounted to $\mathrm{Rp} 34,764,454$, if multiplied, the total indirect cost of Rp7,982,370,576,302.00 meant that the BPKH had to be able to manage the hajj funds. to generate a total benefit value of $6 \%$ of the total hajj funds managed in 2019 to provide subsidies to Indonesian pilgrims. The indirect cost component has a trend that tends to increase every year as graph 1.2 above. If the pilgrimage quota increases 10,000 in the following year it means an indirect cost increase of $\mathrm{Rp}$. $347,644,540,000.00$ bringing the total to $\mathrm{Rp}$ $8,330,015,116,302.00$ or $7 \%$ of the total hajj funds managed in 2019 , this figure is the target for $\mathrm{BPH}$ in the coming years to invest.

The way to overcome the increase in BPIH is to manage the initial deposit of the pilgrims in the right way. One of them is to invest in various investment instruments that are under Law No. 34 of 2014 article 2, namely to the Shariah instrument Investment in Hajj funds in the right instruments can produce returns that are high and create a mechanism to protect potential losses by creating a portfolio consisting of interrelated instruments due to the low correlation between instruments If the risk can be managed it will provide enough probability to achieve the required rate of return.

The available funds must be productive by investing in sectors that quickly generate returns according to investment directives established by law. Thus it is expected that the resulting portfolio returns can be optimal and achieve investment targets. Jogiyanto as cited by Setiawan, Siregar, \& Anggraeni (2015) argues that portfolios formed by investors will be selected based on optimal portfolios in the hope of obtaining maximum results in accordance with the desired level of risk.

Based on Government Regulation No. 5 of 2018 the proportion of investment and placement of funds, which can be carried out by BPKH is as follows First, 3 years since the Hajj Fund Management Board has formed funds in the form of bank products (Savings and Deposits) at most $50 \%$ of the total placements haj funds. After 3 years the maximum placement of banks is reduced to $30 \%$ of the total placement of Hajj funds. Secondly, a maximum of 20 of the total investment placement of Hajj funds is executed into direct investment including ownership of business capital participation, investment cooperation, and other direct investments. Third, a maximum of 5\% of total Hajj financial investment placements are placed in the form of gold either domestic certified gold bars or gold accounts managed by Sharia financial institutions that are regulated and supervised by the Financial Services Authority (The four investments in securities include Sukuk issued by the Central Government and/or by Bank Indonesia, sharia shares listed on the Indonesia Stock Exchange, sharia mutual fund securities, sharia real estate investment funds and other sharia securities The other five investments not included in the above categories with a maximum value of 10 ten percent of the total investment financial placements Hajj (Witjaksono, 2019). 
9 |Arif Setiawan, Hendro Wibowo, Mustafa Kamal : Analysis of 0ptimization Model of Haji Financial Investment Portofolio in BPKH (Haji Financial Management Agency of the Republic of Indonesia)

Based on the explanation above, a study related to portfolio optimization for funds managed by BPKH is important to do. Through this research, it is expected that the investment made by BPKH can produce optimal yields according to the BPKH RI strategic plan and produce investment benefit values that fulfill the main function, namely developing hajj funds so that the benefits for Indonesian hajj pilgrims are large. It is hoped that this study can assist BPKH in formulating an optimal investment portfolio for hajj funds.

\section{LITERATURE REVIEW}

Hajj according to the explanation (Sarwat, 2011) comes from the word al-hajj which means purpose, and the Arabs interpret it by every trip to a place glorified by the Hajjans, then the meaning is devoted by the Shari'a to the Kaaba to carry out the pilgrimage. Therefore, it is said that the pilgrimage is to go to Mecca to perform Hajj rituals, meaning to perform Hajj in its places.

Based on Law No. 34 of 2014 concerning Hajj Financial Management, the Hajj Fund is a fund for depositing the cost of organizing the hajj pilgrimage, the efficiency of organizing hajj funds, the endowment fund of the people, as well as the value of benefits controlled by the state in the context of organizing the hajj pilgrimage and implementing a program of activities to benefit of Muslims.

Investment is the activity of placing an amount of money or funds in the hope of obtaining more benefits in the future on the principal of these funds (Hutajulu, 2015). Additionally, investment means sacrificing a number of dollars in the current time to obtain a number of dollars in the future (W. Sharpe, 1964). Thus investment is the current investment activity to obtain profits in the future. Moeljadi in (Satiti, 2009) said that those who make investments are referred to as Investors. Investors are generally classified into two groups, namely individual investors and institutional investors.

The purpose of investors in investing is to maximize returns, without forgetting investment risk factors that must be addressed. Return is one of the factors that motivates investors to invest and is also a reward for the courage of investors to bear the risk of their investments (Tandelilin, 2010).

Sources of investment return consist of two main components, namely yield and capital gain (loss). Yield is a component of return that reflects the cash flow or income periodically obtained from an investment. If we invest in a bond for example, then the yield is shown from the bond interest paid. Likewise, if we buy shares, the yield is shown by the number of dividends we get. Meanwhile, capital gain (loss) as the second component of return is an increase (decrease) in the price of securities (can be shares or long-term debt securities), which can provide profit (loss) for investors. In other words, capital gains (losses) can also be interpreted as changes in the price of securities (Tandelilin, 2010).

According to (Syaifuddin, 2008) Risk is a deviation from the actual return obtained from the expected rate of return. Investment risk is the risk 
faced by investors of the possibility of not achieving expected returns, due to the uncertainty factor in the future (uncertainty).

Risk in an investment indicates the probability that the return of an asset will deviate from the expected return of the asset. There are two types of risk, namely systematic risk and unsystematic risk (Brigham, 2007). The risk that can be reduced by diversification is an unsystematic risk, which is the risk inherent in each asset. This risk can be avoided by having a portfolio of various companies because the success of each company's strategies can vary. While risks that cannot be eliminated are systematic risks, these risks cannot be eliminated because they affect the whole and systemic, for example, economic recession and inflation.

Modern portfolio theory was first put forward by Harry Markowitz in 1952. According to (Markowitz, 1952), the portfolio selection process is divided into two stages. The first step is to observe and gather information about all available investment instruments to gain confidence in the performance of these assets in the future. The second stage begins with establishing confidence in the performance of assets in the future and ends with portfolio selection.

In portfolio forming, investors should not only maximize returns but investors should diversify rather than maximizing returns. Diversified portfolios can provide better performance Portfolios that maximize returns are not necessarily portfolios that have minimal variance or risk. There is a limit where investors can increase returns by accepting risk or reducing risk by reducing returns (Markowitz, 1952).

Markowitz proposed the theory of an efficient portfolio using two important components, namely, return and risk. An efficient portfolio is a portfolio that has a certain risk with maximum return or a portfolio that has a minimum risk with a certain return. Not only does it encourage diversification, the ideas put forward by Markowitz also advocate diversification well for the right reasons (W. F. Sharpe, 2005).

Adequacy of diversification is not only seen based on the number of types of assets owned, but also seen from whether the portfolio covers various industries. Portfolios with various companies in the same industry are no more diversified than portfolios with various different industries. The reason is, companies in the same industry tend to have poor performance when the industry is not good. From the explanation above, it can be concluded that efforts to minimize risk not only depend on the number of assets owned, but also must pay attention to covariance between assets. Diversification should be done between industries because they tend to have lower covariance.

Asset allocation focuses on the placement of funds in various investment instruments. Not to emphasize the choice of shares in the portfolio. From the results of the study, differences in performance are mainly caused by asset allocation rather than investment choices. According to Markowitz, asset allocation is one of the factors that determines the magnitude of return and risk of the portfolio. In addition to diversification, asset allocation is a very important factor in investment for reasons which are: practically aiming for 
11 | Arif Setiawan, Hendro Wibowo, Mustafa Kamal : Analysis of 0ptimization Model of Haji Financial Investment Portofolio in BPKH (Haji Financial Management Agency of the Republic of Indonesia)

long-term investment; to establish risks that can be tolerated by investors over time and to eliminate changes in investment decisions based on changes in financial conditions.

\section{RESEARCH METHODOLOGY}

\section{Type of research}

This research is quantitative research with a descriptive approach. Quantitative research is research that uses data measured by a numerical scale (Kuncoro, 2013, p. 144). Descriptive research is research that describes a phenomenon related to the research population or estimation of the proportion of the population that has certain characteristics (Cooper, 2017). The purpose of this study is to measure and analyze the optimal investment portfolio of the Indonesian Hajj Fund Management Board at the Republic of Indonesia by using the mean-variance of the investment portfolio Markowitz method. The results of this study are expected to help the Indonesian Republic Hajj Financial Management Agency to decide to determine, evaluate and choose the best policy steps to choose the composition and characteristics of an optimal alternative investment portfolio.

\section{Data Type}

The data source is the subject of where the data was obtained from. Types and sources of data from this study are secondary data. Secondary data is a source of research data obtained indirectly by researchers through intermediary media (obtained and recorded by other parties) according to (Kuncoro, 2013, p. 148) secondary data is data that has been collected by data collection agencies and published to the public. Secondary data is generally in the form of evidence, historical records or reports that have been compiled in archives (documentary data) which are published and which are not published (Supomo, 2016).

\section{Data collection technique}

Data collection techniques are the accuracy of the methods used by researchers to collect data (Kuncoro, 2013, p. 24). In this research, researchers used historical data collection techniques to assess investment instrument performance. Data obtained by browsing the Internet by visiting several sites that provide data needed for research. The following is the data retrieval table

Table. 3.1 Research Instruments

\begin{tabular}{|l|l|l|}
\hline No & Data & Sumber \\
\hline $\mathbf{1}$ & Deposito & Equivalent Rate SBI \\
\hline $\mathbf{2}$ & SDHI & DJP2RR Kemenkeu RI \\
\hline $\mathbf{3}$ & The real sector of hospitality & $\begin{array}{l}\text { Real sector investment } \\
\text { Invetasi of BPS }\end{array}$ \\
\hline
\end{tabular}


Jurnal Ekonomi dan Perbankan Syariah

Vol. 8. No.1, April 2020: 5-27 ISSN (printed): 2355-1755 | ISSN (online): 2579-6437

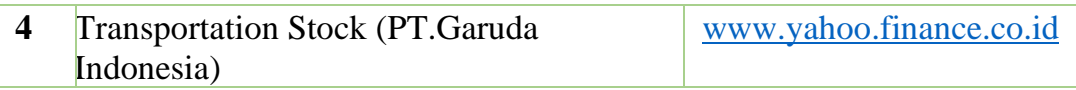

In this study, several notations are used to symbolize expected returns, weights, returns, and standard deviations in the table as follows:

Table 3.2. Investment Instrument

\begin{tabular}{|c|c|c|c|c|c|}
\hline No & Instruments & $\begin{array}{c}\text { Expected } \\
\text { Return }\end{array}$ & weight & Return & Risk \\
\hline 1 & Deposito & $\mathrm{E}\left(\mathrm{r}_{1}\right)$ & $\mathrm{W}_{1}$ & $\mathrm{R}_{1}$ & $\sigma_{1}$ \\
\hline 2 & $\begin{array}{c}\text { Transportation } \\
\text { stock (PT.Garuda } \\
\text { Indonesia) }\end{array}$ & $\mathrm{E}\left(\mathrm{r}_{2}\right)$ & $\mathrm{W}_{2}$ & $\mathrm{R}_{2}$ & $\sigma_{2}$ \\
\hline 3 & SDHI & $\mathrm{E}\left(\mathrm{r}_{3}\right)$ & $\mathrm{W}_{3}$ & $\mathrm{R}_{3}$ & $\sigma_{3}$ \\
\hline 4 & $\begin{array}{c}\text { The real sector of } \\
\text { hospitality }\end{array}$ & $\mathrm{E}\left(\mathrm{r}_{4}\right)$ & $\mathrm{W}_{4}$ & $\mathrm{R}_{4}$ & $\sigma_{4}$ \\
\hline
\end{tabular}

\section{Population and Sample}

In this study, assets used in optimal portfolio formation refer to PP No. 5 of 2018 (see Table 1.3). Return on investment instruments in the form of Islamic banking deposits are calculated using the SBI equivalent rate, SBSN Indonesian Hajj Sukuk funds refer to the returns listed in the last series of securities. Return from the placement of Islamic shares, using the return of BUMN airlines in this case PT. Garuda Indonesia and the real sector return look at investment statistics reports on the BPS (Statistics Indonesia) in the hospitality sector.

\section{Data analysis technique}

The stages of data processing and data analysis carried out are as follows: (1) Performance analysis for each type of investment instrument and for the portfolio formed on the investment of Indonesian hajj funds (By calculating the return and risk of each type of investment, portfolio return and risk, and Sharpe ratio). (2) Determination of the optimal portfolio with the help of Microsoft's Excel Solver program.

Historical data is then processed with the help available on a computer program that is Microsoft software Excel is very helpful in data processing including stdevp (calculating standard deviations), Average (calculating average), correl (calculating correlations), covar (calculating covariance) and varp (counting variants). In addition to the additional feature functions in Microsoft Excel software it is very necessary in processing this data, especially the solver feature. This additional feature has the utility to provide a value solution to a linear programming equation by specifying a value criterion with some constraints or limits on the objective function.

Besides its usefulness, the advantage of Microsoft Excel software is that this program is easily applied to the portfolio calculation procedure using the markowits method used in this study. Easy to use by those who need (user friendly) and is one of the popular software circulating in the community. 
13 | Arif Setiawan, Hendro Wibowo, Mustafa Kamal : Analysis of 0ptimization Model of Haji Financial Investment Portofolio in BPKH (Haji Financial Management Agency of the Republic of Indonesia)

\section{a) Analyze Return of Individual Assets}

The rate of return of an asset is calculated by calculating the difference in value at time $\mathrm{t}$ and $\mathrm{t}-1$ divided by the value at time $\mathrm{t}$.

Keterangan:

$$
R_{a}=\frac{P_{t}-P_{t-1}}{P_{t-1}}
$$

Ra : Return Aset

Pt : Harga pada periode bersangkutan

Pt-1 : Harga pada periode sebelumnya

1) Deposito

Information:

$$
R_{n}=\frac{R_{y}}{12}
$$

Ry: Annual Return

Rn: Monthly Returns

2) Stocks

The basis for consideration is the use of Individual Stock Price Index (IHSI) data compared to the Composite Stock Price Index (CSPI), assuming cash dividends are not used because the value is too small so that it has little effect on the results (Rolanda, 2014).

Information:

$$
R_{n}=\frac{I H S I t-I H S I_{t-1}}{I H S I_{t-1}}
$$

IHSIt: Index of individual stock prices in the month $t$

IHSIt-1: Index of individual stock prices in month t-1

2) Sukuk

$$
R_{n}=\frac{P_{t}-P_{t-1}+C}{P_{t-1}}
$$

Information:

Pt: Sukuk prices for the period

Pt-1: Price of sukuk in the previous period

C: Profit-sharing or margin

\section{b). Analyzing Individual Risk}

Calculation of individual risk analysis equations using standard deviations as stated by Markowitsz (W. Sharpe, 1964, p. 77)

$$
\sigma=\sum_{i=1}^{n} \frac{\sqrt{\left([(X-X)]^{2}\right)}}{n-1} \quad-
$$

information:

$\sigma:$ Standard deviation

$\mathrm{X}$ : Asset Prices at one time 
Jurnal Ekonomi dan Perbankan Syariah

Vol. 8. No.1, April 2020: 5-27 ISSN (printed): 2355-1755 | ISSN (online): 2579-6437

$\mathrm{X}$ : Average Assets

$\mathrm{n}$ : Number of Observations

To simplify risk research, it is calculated with the stdev (argument) function in Microsoft Excel software, where the argument contains the data return instrument during the study period.

\section{a). Calculating return and portfolio risk}

The formula for calculating the expected return from a portfolio is as follows jones in (Manulang, 2012):

$$
E(R p)=\sum_{i=1}^{n} W i E(R i)
$$

Information:

$\mathrm{E}(\mathrm{Rp})$ : expected return from the portfolio

$\mathrm{Wi} \quad$ : the weight of i-securities portfolio

$\sum W_{i} \quad$ : total portfolio weight $=1.0$

$\mathrm{E}(\mathrm{Ri}) \quad$ : expected return dari sekuritas ke-i

$\mathrm{N} \quad$ : number of securities in the portfolio

\section{b). Calculating Portfolio Risk}

The next step is to calculate portfolio variants. In calculating portfolio variants, the portfolio standard deviation is calculated first. The standard deviation of the portfolio is the square root of the portfolio variant. Portfolio variants are obtained by multiplying the covariance between instruments with the weight of each instrument in the portfolio.

This risk gauge will identify the magnitude of the deviation from the average. Mathematically, the formula for calculating n-asset risk is (W. Sharpe, 1964)

$$
\sigma_{p}^{2}=\sum_{i=1}^{n} W i^{2} \sigma^{2}+\sum_{\substack{i=1 \\ \text { And } \\ i \neq j}}^{n} \sum_{i=1}^{n} W_{i} W_{j} W_{i j}
$$

\section{Information}

$\sigma$ : Variance of portfolio return

$\sigma \mathrm{p} 2$ : asset return variance $\mathrm{i}$

$\sigma \_\mathrm{ij}$ : Covariance between return assets $\mathrm{i}$ and $\mathrm{j}$

$\mathrm{Wi}$ : the weight invested in assets $\mathrm{i}$

$\mathrm{Wj}$ : weight invested in assets $\mathrm{j}$

The calculation of portfolio variance above can be explained using the help of the matrix in the Microsoft Excel matrix program. Then the variance of a portfolio consisting of $n$-assets can be easily calculated by adding up the cells in the matrix. 
15 | Arif Setiawan, Hendro Wibowo, Mustafa Kamal : Analysis of 0ptimization Model of Haji Financial Investment Portofolio in BPKH (Haji Financial Management Agency of the Republic of Indonesia)

\section{a) Analyzing Covariance and Correlation}

Covariance calculations can be done using the formula, (W. Sharpe, 1964) viz:

$$
\operatorname{Cov}\left(R_{A}, R_{B}\right)=\sigma_{A B}=\sum_{i=1}^{n} \frac{\left[\left(R_{A i}-E\left(R_{A}\right)\right) \cdot\left(R_{B i}-E\left(R_{B}\right)\right]\right.}{n-1}
$$

Information:

Cov (RA, RB): Covariance of both assets A and B

RA: Assets A

RB: Assets B

RAi: Weight invested in asset A

$\mathrm{RBi}$ : Weight invested in asset B

Tandelilin (2010, p. 32) states that covariance is an absolute measure that indicates the extent to which two variables have a tendency to move together. In the context of portfolio management, covariance shows the extent to which returns from two assets have a tendency to move together. The covariance calculation is done by the equation formula (Kothari \& Warner, 2001, p. 43)

The correlation coefficient is used for whether a variable can be related to other variables. If there is a relationship how the relationship between these two variables. Mathematically, the correlation can be calculated using the following formula Jones in (Manulang, 2012):

$$
P_{A B}=\frac{\operatorname{Cov}_{A B}}{\operatorname{Cov} A \operatorname{Cov} B}
$$

By knowing covariance, the correlation coefficient can be determined using the equation:

$\operatorname{Cov}(R A, R B)=\sigma A B=\rho . \sigma A \sigma B$

The correlation coefficient shows the magnitude of the relationship between the two variables relative to each deviation. In statistics, the correlation coefficient is between two extreme values, namely perfect positivity $(+1)$, which means a perfect strong directional relationship, and perfect negative correlation (-1) which means a perfectly strong inverse relationship, while the correlation coefficient $(0)$ shows no there is a correlation.

To simplify the calculation, the correl function (argument1, argument2) is used where argument 1 contains the 1 st data return instrument and the 2 nd argument contains the 2 nd data return instrument during the study period.

\section{a) Optimal Portfolio}

Evaluate the BPKH Hajj Investment Fund diversification strategy to determine the portfolio that provides optimal results, both those that provide a higher level of return or those that provide less risk with the following steps.

1. Determine the portfolio with the smallest risk (global minimum variance).

2. Forming an investment portfolio scenario to get an efficient portfolio alternative with the same expected level of expected return This study 
analyzes the formation of the BPKH RI Hajj Fund Investment portfolio. The data used is monthly data for the period January 2017December 2019 and is limited to 4 types of investment instruments, namely deposits, sukuk, stocks and the real sector.

The data used in this research is secondary data. Data is internal or external to the organization and accessed through the internet, document searches, or publication of information.

Data collection is done by library research. Literature data is obtained from theoretical books, the internet, literature studies and other information that is considered relevant and supports research. Some data sources are Bank Indonesia, the Indonesian Hajj Financial Management Agency and the Central Statistics Agency, www.yahoofinance.com.

b) Determination of Optimal Portfolios

By utilizing information on 4 investment instruments, namely, deposits, sukuk, shares, an analysis will be carried out aimed at determining the optimal portfolio

\section{1) Global Minimum Variance Portfolio (GMV Portfolio)}

The GMV portfolio has the lowest risk level of the entire efficient portfolio composition resulting from the Efficient Frontier (Zivot, 2016). Following are the steps to find a GMV portfolio.

Objective Function:

$$
\begin{array}{ll}
\text { Minimizen }= & \mathrm{W}_{1} \mathrm{~W}_{1} \sigma_{11}+\mathrm{W}_{2} \mathrm{~W}_{2} \mathrm{~s}_{22}+\mathrm{W}_{3} \mathrm{~W}_{3} \sigma_{33}+2 \\
\text { VAR }(\mathrm{RP}) & \mathrm{W}_{1} \mathrm{~W}_{2} \sigma_{12}+2 \mathrm{~W}_{1} \mathrm{~W}_{3} \sigma_{13}+2 \mathrm{~W}_{2} \mathrm{~W}_{3} \sigma_{23}
\end{array}
$$

Terms / limitations

$\mathrm{W} 1+\mathrm{W} 2+\mathrm{W} 3+\mathrm{W} 4=1$

Information:

W1: Deposit weight

W2: Weight of shares

W3: Sukuk weight

W4: Hospitality weight

$\mathrm{Wi}$ is greater than or equal to zero $(\mathrm{Wi}=0)$.

The above equation can be solved with the help of the MS Excel Solver computer program.

\section{1) Optimal Portfolios at Certain Expected Returns}

In calculating, a method is almost the same as looking for a GMV portfolio with the addition of a limiting function. The equation used is as follows:

\section{Objective Function:}

$$
\begin{array}{ll}
\operatorname{Max}= & \mathrm{W}_{1} \mathrm{~W}_{1} \sigma_{11}+\mathrm{W}_{2} \mathrm{~W}_{2} \mathrm{~s}_{22}+\mathrm{W}_{3} \mathrm{~W}_{3} \sigma_{33}+2 \\
\operatorname{VAR}(\mathrm{RP}) & \mathrm{W}_{1} \mathrm{~W}_{2} \sigma_{12}+2 \mathrm{~W}_{1} \mathrm{~W}_{3} \sigma_{13}+2 \mathrm{~W}_{2} \mathrm{~W}_{3} \sigma_{23}
\end{array}
$$

\section{Terms / limitations}


17 | Arif Setiawan, Hendro Wibowo, Mustafa Kamal : Analysis of 0ptimization Model of Haji Financial Investment Portofolio in BPKH (Haji Financial Management Agency of the Republic of Indonesia)

- $\mathrm{W} 1+\mathrm{W} 2+\mathrm{W} 3+\mathrm{W} 4=1$

- $\mathrm{Wi}$ value is greater than or equal to zero $(\mathrm{Wi}=0)(R p)=$ $\sum_{i=1}^{n} W i E(R i)$

The above equation can be solved with the help of the MS Excel Solver computer program by adding a boundary condition $\mathrm{E}(\mathrm{Rp})$.

\section{a) Sharpe Ratio}

Analysis of return relative to the risk used in this study is the Sharpe ratio. Sharpe ratio measures how much expected return is generated for each unit of total risk. A positive Sharpe ratio shows that the investment portfolio formed can provide additional investment returns that are greater than risk free assets. Risk free asset indicator used in this study is to use the BI rate. The higher the positive value of the Sharpe ratio, the better the performance of the portfolio or the smaller the Sharpe ratio, the investment portfolio the more risky (W. Sharpe, 1964).

Measuring Portfolio Performance, the Sharpe ratio bases its calculations on the concept of a capital allocation line as a benchmark, namely by dividing portfolio risk premium by its standard deviation. Thus, the sharpe ratio can be used to measure the risk premium for each unit of risk in the portfolio. To calculate the Sharpe ratio the following equation can be used (Jones, 2009):S $p=\frac{E\left(R_{p}\right)-R_{f}}{\sigma_{p}}$

Information

$\begin{array}{ll}S p & : \text { Sharpe Ratio } \\ R p & : \text { Return Portfolio } \\ \mathrm{Rf} & : \text { Risk Free Asset } \\ \sigma_{\mathrm{p}} & : \text { Risiko Portfolio }\end{array}$

a) Data analysis Steps

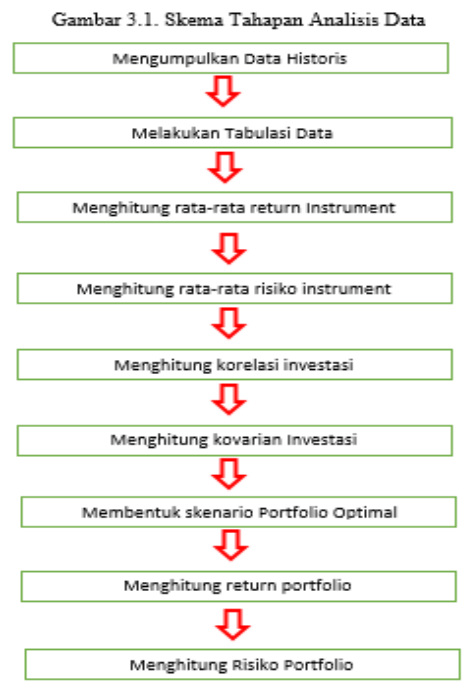


Jurnal Ekonomi dan Perbankan Syariah

Vol. 8. No.1, April 2020: 5-27 ISSN (printed): 2355-1755 | ISSN (online): 2579-6437

\section{ANALYSIS AND DISCUSSION}

\section{Overview of Research Objects}

The Hajj Financial Management Agency is a legal entity that was formalized by the State and is an independent institution that has the task of managing Hajj finance. This body was established in 2017. The Hajj Financial Management Agency is headquartered in Menara Bidakara 1, 5th floor Jalan Gatot Subroto, Kav. 71-73 Pancoran, South Jakarta 12870, Indonesia. BPKH stands for the purpose of optimizing services to pilgrims specifically in terms of financial management. Previously the pilgrimage fund was managed by the ministry of religion before finally this role was transferred to a separate agency separate from the ministry namely BPKH RI.

\section{Analysis and Discussion}

Optimal portfolio analysis in an investment begins by analyzing the return of each investment instrument. according to the critics in (Manulang, 2012) states that returns are income generated from an asset, added or subtracted by some price changes that occur during a certain period, all divided by the price of assets at the beginning of the period. According to Levy in (Manulang, 2012) states that the expected yield is an average of the potential level. Expected return is also known as mean return or average return is simplified to mean. Expected returns have two components, namely the probability and the rate of return on assets. To calculate the expected return, the researcher uses the average return of each investment instrument during the observation period, which is 2017 to 2019.

Analysis of investment portfolio return and risk can be done by first knowing the risk-return profile of various investment assets available, namely sharia banking deposits, hajj sukuk funds, stocks, direct investments (real hotel sector). The risk-return profile of the various asset groups can be determined by analyzing observational data. The initial step in processing data is to calculate the average yield. From the yield data obtained, it can be calculated the average return (expected return) in the entire study period for each instrument. Namely by dividing the entire amount of instrument yields in the study period by the period of the number of research months. Can be used average function assistance on Microsoft Excel software with the assumption that each return throughout the study period, then the expected return per instrument is shown in Table 1.

In this table, all data are displayed using the yield unit, which is the percentage change in price for the Garuda stock price index. While for Islamic banking deposits, the data shown is the value of the Islamic banking deposit equivalent to the equivalent rate and for direct investments, the data shown in table 4.1 is annual return data obtained from the Central Statistics Agency. Thus, the yield levels of various investment asset groups can be directly distinguished. The data displayed in the average column and standard deviation is yield rate data that has been processed into monthly. 
19 | Arif Setiawan, Hendro Wibowo, Mustafa Kamal : Analysis of 0ptimization Model of Haji Financial Investment Portofolio in BPKH (Haji Financial Management Agency of the Republic of Indonesia)

Table 4.2 Investment return instrument profiles (in\%)

\begin{tabular}{|c|c|c|c|c|}
\hline $\begin{array}{c}\text { Individual } \\
\text { Return }\end{array}$ & 2017 & 2018 & 2019 & Mean \\
\hline Deposito & 0,0465 & 0,0527 & 0,0563 & 0,0518 \\
\hline Stock & 0,0115 & 0,0026 & 0,0565 & 0,0235 \\
\hline Sukuk & 0,0516 & 0,0606 & 0,0690 & 0,0604 \\
\hline Real Sector & 0,1729 & 0,0747 & 0,0277 & 0,0918 \\
\hline
\end{tabular}

Source: Data processed

The next management step is to calculate risk (standard deviation) throughout the entire study period for each instrument. risk is the root of the variant, so the calculation of risk is in line with calculating the variant. can be used to help stdevp function on Microsoft Excel software with the argument of each return throughout the study period, then the risk obtained per instrument shown in table 4.2 .

Table 4.3 Profile of Expected return and Risk of investment instruments

\begin{tabular}{|c|c|c|}
\hline Aset & E(Ri) & Risk \\
\hline Deposit & 0,0518 & 0,0057 \\
\hline Stocks & 0,0235 & 0,1703 \\
\hline Sukuk & 0,0604 & 0,0121 \\
\hline Real Sector & 0,0918 & 0,0741 \\
\hline
\end{tabular}

Source: Data processed

Table 4.3 above shows that Islamic banking deposits have an average rate of return of 0.0518 and the lowest risk compared to other investment asset groups, namely 0.0057 . The matter in the processed data above shows that the movement of the rate of return on deposits is relatively stable, which ranges from 5\% - 6\% during the period 2017 - 2019. With the level of risk and the rate of return, deposits in Islamic banking can be classified as riskless assets or assets with a risk free, although the possibility of default investment in Islamic banking still exists, the percentage is very small. The existence of the Deposit Insurance Corporation (LPS) in Islamic banking, allows the anticipation of losses on default risk to be very low.

Table 4.3 above shows the risk-return profile of sukuk as one of the mainstay instruments for BPKH to invest especially in Indonesian Hajj sukuk funds. The performance of Indonesian Hajj sukuk funds is relatively good with an average rate of return of 0.0604 per year and a standard deviation of 0.0121 . When compared to deposits, the average yield rate of sukuk is slightly higher, but in terms of risk, sukuk has a higher level when compared to deposits. The initiation of the placement of the hajj funds was first carried out by Ms. Sri Mulyani Indrawati when she served as Minister of Finance in the first period of 2009. SDHI began when the Minister of Finance and Minister of Religion signed an agreement (MoU) on April 22, 2009. The contents of the MoU were an agreement for the placement of hajj funds and endowments of the ummah 
to the State Sharia Securities (SBSN) by private placement (Hariyanto, 2016). Underlying the placement of Hajj funds in SBSN is a safety factor in investing and benefits in the form of SBSN rewards. So far, using SDHI which is a private placement has given an advantage to the Ministry of Religion in determining the tenor of SDHI that is adjusted to the planned utilization of these funds. However, SDHI is a non-tradable instrument so it cannot be redeemed at any time (Hariyanto, 2016) different from other sukuk. The reason for the pilgrimage fund is placed in SDHI and not in other sukuk because of the character of the pilgrimage fund itself, that all forms of investment must be based on the importance of improving the pilgrimage service so that a special Hajj container is needed for investment. Besides that, in other sukuk instruments there are limited funds placed such as in retail sukuk, for example, it is limited to a maximum of 5 billion for each person (Ministry of Finance, 2017)

Stock as one of the risky assets has a lower return profile compared to other investment groups. The average return on shares during the period $2017-2019$ is 0.0235 per year with a standard deviation of 0.1703 , which also makes it the highest asset in the standard deviation compared to other asset groups. The financial performance of PT Garuda Indonesia indeed tends to decline, this is proven in research (Biantara \& Handayani, 2020) that the financial performance of PT Garuda Indonesia is experiencing a decline but the assets owned by PT Garuda continue to increase. Even so PT Garuda Indonesia is the healthiest air transportation company among other companies (Pratiwi, 2020). In addition this company is also a state-owned company, which means that it is owned by the State so that its performance can affect the country's economy. The need for pilgrims to air transportation will never be separated because the departure of pilgrims to the holy land requires air transportation and this sector is one of the major cost components of pilgrims. In the future, it is hoped that BPKH will be able to project investment in air transportation to improve the services of pilgrims because air transportation is a basic need for pilgrims (Permana, 2019).

the real sector for hospitality is an instrument with the highest average yields among other investment groups, which is 0.0918 with a standard deviation that is 1 level lower than stock instruments but is greater than sukuk which is 0.0741 . This sector is an important sector in the case of Hajj because lodging is a basic need for pilgrims.

Correlation coefficient or correlation abbreviated is a statistical measure used to see the relationship between the yield of individual instruments or the tendency of two instruments to move together.

The return correlation coefficient between the two instruments is calculated with the help of the statistical correlation function in Microsoft Excel software with the argument of the entire yield of the two instruments. The results of the calculation of the correlation coefficient are presented in the form of a matrix which can be seen in Table 4.3.

From table 4.3 , it can be seen that the correlation between instruments ranged from $-0.0927<p<0.588$. No one instrument is positively correlated to 
21 | Arif Setiawan, Hendro Wibowo, Mustafa Kamal : Analysis of 0ptimization Model of Haji Financial Investment Portofolio in BPKH (Haji Financial Management Agency of the Republic of Indonesia)

all other instruments, such as the deposit instrument which is positively correlated with stocks and SDHI, respectively 0.195 and 0.588 but negatively correlates with the real sector by 0.717 . There is one instrument that is negatively correlated with all other instruments, namely the Real instrument sector. Real sector instruments are negatively correlated with deposits, stocks and SDHI respectively $0.717,0.0927,0.782$

Table 4.5 Correlation Coefficients of Investment Instruments

\begin{tabular}{|l|l|l|l|l|}
\multicolumn{1}{|c}{ Korelasi } & \multicolumn{1}{c}{ Deposito } & \multicolumn{1}{c|}{ Saham } & \multicolumn{1}{c|}{ SDHI } & $\begin{array}{c}\text { Real } \\
\text { Sector }\end{array}$ \\
\hline Deposito & 1 & & & \\
\hline Saham & 0,195783377 & 1 & 1 & \\
\hline SDHI & 0,588384046 & 0,142472075 & 1 & 1 \\
\hline Real Sector & $-0,717099353$ & $-0,092746917$ & $-0,78204$ & 1 \\
\hline
\end{tabular}

Source: data processed

Stock instruments are positively correlated to deposit instruments by 0.195 and SDHI by 0.588 , which means the stock return instrument moves together with the yields of the above-mentioned instruments. Can be seen in the correlation between SDHI to shares of 0.142 , meaning that if the yield of the SDHI instrument has increased by one unit, the yield of stock instruments has increased by 0.142 units. And if the yield of the SDHI instrument falls by one unit, the shared instrument will also tend to decrease by 0.142 one unit. And the real sector instrument which has a negative correlation with all existing investment instruments means that the real sector instrument moves in contrast to all the existing instruments in terms of yields. Missal on the correlation between real sector instruments with deposit instruments where where the deposit instrument has increased by one unit then the real sekor instrument tends to decrease by 0.717 one unit and vice versa.

By knowing the correlation characteristics as above, investors can develop strategies to diversify their asset portfolio to reduce risk when compared to the risk of each asset.

\section{a). Conservative portfolio composition}

Table. 4.6 Conservative Scenarios (in \%)

\begin{tabular}{|c|c|c|c|c|}
\hline $\begin{array}{l}\text { Investment } \\
\text { instrument }\end{array}$ & Deposito & Stock & Sukuk & Real sector \\
\hline Bobot & $50 \%$ & $0 \%$ & $50 \%$ & $0 \%$ \\
\hline $\begin{array}{l}\text { Total } \\
\text { Bobot }\end{array}$ & \multicolumn{4}{|c|}{$100 \%$} \\
\hline $\begin{array}{l}\text { Expected } \\
\text { Return }\end{array}$ & \multicolumn{4}{|c|}{$7,76 \%$} \\
\hline
\end{tabular}


Jurnal Ekonomi dan Perbankan Syariah

Vol. 8. No.1, April 2020: 5-27 ISSN (printed): 2355-1755 | ISSN (online): 2579-6437

\begin{tabular}{|c|c|}
\hline Risiko & $1,09 \%$ \\
\hline $\begin{array}{c}\text { Sharped } \\
\text { Ratio }\end{array}$ & 2,52448208 \\
\hline
\end{tabular}

Source: Data processed

As can be seen in table 4.6 some compositions must be allocated in conservative optimization studies conducted to try to allocate assets to low risk. The calculation result of the function shows that the asset allocation to deposits is $50.00 \%$ and SDHI is $50.00 \%$. With this combination, the portfolio can reach the expected return rate of $7.76 \%$ per year and the risk level of $1.09 \%$ with a Sharpe ratio of 2.471519. This composition is enough to get a yield even though it is still relatively low, but this combination has a safety risk. This is what is currently still being done by BPKH allocating assets to risk-free instruments namely deposits and sukuk.

\section{b). Moderate portfolio composition}

Table 4.7 Moderate Scenarios (in\%)

\begin{tabular}{|c|c|c|c|c|}
\hline $\begin{array}{c}\text { Instrument } \\
\text { Investasi }\end{array}$ & Deposito & Saham & Sukuk & Real sector \\
\hline Weight & $30 \%$ & $5 \%$ & $60 \%$ & $5 \%$ \\
\hline Total & \multicolumn{4}{|c|}{$100 \%$} \\
\hline $\begin{array}{l}\text { Expected } \\
\text { Return }\end{array}$ & \multicolumn{4}{|c|}{$14,70 \%$} \\
\hline Risiko & \multicolumn{4}{|c|}{$3,22 \%$} \\
\hline $\begin{array}{c}\text { Sharpe } \\
\text { Ratio }\end{array}$ & \multicolumn{4}{|c|}{3,013616247} \\
\hline
\end{tabular}

Source: Data processed

In table 4.7 the results of the optimization function performed show that the allocation of assets to deposits amounted to $30.00 \%$ and to Sukuk amounted to $60.00 \%$, in this composition began to distribute assets to the direct investment sector ie shares of $5.00 \%$ and the real sector of $5.00 \%$. With this combination the portfolio is able to achieve an expected return rate of $14.70 \%$ per year and a risk level of $3.22 \%$. This figure has increased almost two times from the conservative model because this investment began to be allocated to assets that have high returns. But the increase in risk is also quite significant from the conservative model where the risk level is three times greater than the conservative. The gap between the expected return and the risk is quite far, but if it is in the form of monthly returns, the expected return will be $1.225 \%$ and the risk will be $0.929 \%$. 
23 | Arif Setiawan, Hendro Wibowo, Mustafa Kamal : Analysis of 0ptimization Model of Haji Financial Investment Portofolio in BPKH (Haji Financial Management Agency of the Republic of Indonesia)

\section{c). Portfolio Composition in Aggressiveness}

Table. 4.8 Aggressive Scenarios

\begin{tabular}{|c|c|c|c|c|}
\hline $\begin{array}{l}\text { Instrument } \\
\text { Investasi }\end{array}$ & Deposito & Saham & Sukuk & Real sector \\
\hline Weight & $10 \%$ & $10 \%$ & $65 \%$ & $15 \%$ \\
\hline Total & \multicolumn{4}{|c|}{$100 \%$} \\
\hline $\begin{array}{l}\text { Expected } \\
\text { Return }\end{array}$ & \multicolumn{4}{|c|}{$26,62 \%$} \\
\hline Risiko & \multicolumn{4}{|c|}{$6,39 \%$} \\
\hline $\begin{array}{c}\text { Sharpe } \\
\text { Ratio }\end{array}$ & \multicolumn{4}{|c|}{3,385519734} \\
\hline
\end{tabular}

Source: processed data

In table 4.8 the results of the optimization function carried out for the aggressive level show that the allocation of assets to deposits amounted to $10.00 \%$ and to Sukuk by $65.00 \%$, in this composition the allocation of assets to the investment sector is directly increased because of its orientation to obtain high returns then the portion for shares is $10.00 \%$ and the real sector is $15.00 \%$. With this combination the portfolio is able to achieve an expected return rate of $26.62 \%$ per year and a risk level of $6.39 \%$ per year. Increased significant returns with the level of risk. This figure increased by almost twice the moderate model. We see the return and risk in the form of monthly, the expected return becomes $2.218 \%$ and the risk becomes $1.843 \%$. This gap between return and monthly risk is not too far away, which means that the potential risk of this portfolio is also huge because the direct investment sector, both stocks and real sectors, has a high risk.

The results of the optimization of the composition of the assets above have been through functions in the research methods used and with the solver program at Microsoft Excel.

\section{d). Global Minimum Variance}

Determination of the Optimal Portfolio with the approach used by the Global Minimum Variance Portfolio (GMV Portfolio). The solution produced by MS Excel Solver is as follows.

Table 4.9 GMV Portfolio (Global Minimum Variant)

\begin{tabular}{|c|c|c|c|c|}
\hline $\begin{array}{c}\text { Instrument } \\
\text { Investasi }\end{array}$ & Deposito & Saham & Sukuk & Sektor Real \\
\hline Weight & $98,99 \%$ & $0 \%$ & $0,42 \%$ & $0,59 \%$ \\
\hline $\begin{array}{c}\text { Total } \\
\text { Weight }\end{array}$ & & \multicolumn{3}{|c|}{$100 \%$} \\
\hline
\end{tabular}


Jurnal Ekonomi dan Perbankan Syariah

Vol. 8. No.1, April 2020: 5-27 ISSN (printed): 2355-1755 | ISSN (online): 2579-6437

\begin{tabular}{|c|c|}
\hline $\begin{array}{c}\text { Expected } \\
\text { Return }\end{array}$ & $5,81 \%$ \\
\hline Risk & $0,21 \%$ \\
\hline $\begin{array}{c}\text { Sharpe } \\
\text { Ratio }\end{array}$ & 3,385519734 \\
\hline
\end{tabular}

Source: processed data

The composition of instruments $\mathrm{W} 1, \mathrm{~W} 2, \mathrm{~W} 3$, and $\mathrm{W} 4$ above are portfolio compositions that have the lowest risk of all available diversification opportunities. The portfolio composition allocates assets on deposits of $98.99 \%$, on sukuk of $0.42 \%$, and on the real sector $0.59 \%$. The results of this function do not place a portion of the stock asking that the level of risk in the stock is the highest among other instruments. The above composition will produce a risk of $0.21 \%$ per year and an expected return of $5.81 \%$ per year. If you look at the monthly time, the rate of return is $0.484 \%$ per month and the risk of $0.333 \%$ per month is a very small number but categorized as safe because of the small risk.

The results of the optimization with the function above puts assets into deposits very large, this is because the lowest level of risk sought in investing. Therefore this composition is not relevant when applied to BPKH because it is not following the existing strategic plan. However, what we can see is that there is still a portion for the real sector even though the instrument is included in risk categories. This means the function of reading the optimization of investment returns at the lowest risk level.

\section{CONCLUSION}

Based on the results of the study that have been presented (Analysis and Discussion), conclusions can be drawn, as follows:

1. Portfolios in the moderate scenario provide a return of $14.70 \%$ and have a risk level of $3.22 \%$ per year with a $30 \%$ deposit composition, $60 \%$ Sukuk, and $5 \%$ in stocks and the real sector. This portfolio has exceeded the BPKH strategic plan target and this composition is the composition to obtain the expected return at a certain level of risk.

2. Portfolio in the aggressive scenario the expected rate of return rises significantly by $26.62 \%$ and the risk of $6.39 \%$ with the composition of deposits $10 \%, 65 \%$ Sukuk and $10 \%$ in shares, and $15 \%$ in the real sector. This portfolio is the composition that gives the maximum return on investment.

3. The portfolio in the conservative scenario with a composition of $50 \%$ and $50 \%$ deposits in Sukuk can provide fairly optimal returns with a yield rate of $7.76 \%$ per year and a risk level of $1.09 \%$. This portfolio is a portfolio that provides returns according to the BPKH strategic plan targets and the minimum risk. 
25 | Arif Setiawan, Hendro Wibowo, Mustafa Kamal : Analysis of 0ptimization Model of Haji Financial Investment Portofolio in BPKH (Haji Financial Management Agency of the Republic of Indonesia)

\section{BIBLIOGRAPHY}

Abdi, M. N., \& Hidayat, M. (2017). Analisis Pengaruh Faktor-Faktor Resiko Investasi Terhadap Perusahaan Farmasi Yang Listing Di Bursa Efek Indonesia. Jurnal Economix, 4(1), 203-214.

Abidin, M. Z. (2016). Analisis Investasi Dana Haji Dalam Pembiayaan Infrastruktur Dan Peningkatan Kualitas Penyelenggaraan Ibadah Haji. Harmoni, (Mei-Agustus), 152-164.

Asfiroyan, M. (2017). Optimalisasi Dana Haji Dalam Pembangunan Sektor Riil Melalui Skema Project Based Sukuk (Pbs). Jurnal Pkn Stan.

Biantara, D., \& Handayani, S. (2020). Analisis Internal Audit Dan Kinerja Perusahaan Terhadap Harga Saham Pada Pt . Garuda Indonesia Audit Laporan Keuangan, Ruang Lingkup. Acounting Cycle Journal, 1(1), 4788.

Cooper, D. R. (2017). Metode Penelitian Bisnis. Jakarta: Salemba Empat.

Daulay, A. N. (2017). Faktor-Faktor Yang Berhubungan Dengan Perkembangan Produk Tabungan Haji Perbankan Syariah Di Indonesia. Human Falah, 4, 106.

Friantoro, D. (2018). Menggangas Badan Usaha Milik Haji (Bumh) Ikhtiar Mencari Model Investasi Yang Bernilai Maslahat. Bidang Perencanaan \& Pengembangan Bpkh.

Hariyanto, E. (2016). Investasi Dana Haji Pada Sukuk Infrastruktur. Kementrian Keuangan.

Hutajulu, D. (2015). Manajemen Investasi. In Manajemen Investasi (P. 57).

Intan, P. S., \& Ahmad, N. (2019). Analisis Portofolio Efisien Sembilan Sektor Industri Berdasarkan Tingkat Imbal Hasil Dan Resiko. (March).

Kasri, R. E. A. (2018). Laporan Akhir Kajian Akademik Pengelolaan Keuangan Haji Tahun Anggaran 2018: Strategic Assets Allocation Untuk Optimalisasi Pengelolaan Investasi Dana Haji Di Indonesia. Jakarta.

Kementrian Agama. (2018). Tuntunan Manasik Haji \& Umrah. In Dirjen Penyelenggaraan Haji Dan Umrah (Vol. 53). Https://Doi.Org/10.1017/Cbo9781107415324.004

Kementrian Keuangan. (2017). Investasi Syariah Melalui Surat Berharga Syariah Negara ( Sukuk Negara ). Pp. 1-21.

Kothari, S. P., \& Warner, J. B. (2001). Evaluating Mutual Fund Performance. Journal Of Finance, 56(5), 1985-2010. Https://Doi.Org/10.1111/00221082.00397

Kuncoro, M. (2013). Metode Riset Untuk Bisnis Dan Ekonomi Bagaimana Meneliti Dan Menulis Tesis? (4th Ed.; W. Hardani, Ed.). Jogjakarta: Penerbit Erlangga.

Luois, G., Latif, I. N., \& Verahastuti, C. (2019). Analisis Portofolio Saham Pada Perusahaan Sub Sektor Pertambangan Yang Terdaftar Di Bursa Efek Indonesia ( Bei ) Dengan Pendekatan Capital Asset Pricing Model ( Capm ) Dan Arbitrage Pricing Theory ( Apt ). Journal Of Indonesian 
Jurnal Ekonomi dan Perbankan Syariah

Vol. 8. No.1, April 2020: 5-27 ISSN (printed): 2355-1755 | ISSN (online): 2579-6437

Science Economic Research, 1(2), 12-19.

Manulang, M. P. (2012). Optimalisasi Kinerja Portofolio Investasi Di Indonesia Optimalisasi Kinerja Portofolio Investasi Di Indonesia. 1-22. Markowitz, H. (1952). Portfolio Selection. The Journal Of Finance, 77-91.

Muneeza, A., Sudeen, A., Nasution, A., \& Nurmalasari, R. (2018). A Comparative Study Of Hajj Fund Management Institutions In Malaysia, Indonesia And Maldives. International Journal of Management And Applied Research, 5(3), 120-134. Https://Doi.Org/10.18646/2056.53.18-009

Permana, F. E. (2019). Bpkh Disarankan Investasi Syariah Sektor Transportasi Udara. Republika. Https://Doi.Org/10.1017/Cbo9781107415324.004

Pp Nomor 5 Tahun 2018. (N.D.). Pp Nomor 5 Tahun 2018 Tentang Pengelolaan Keuangan Haji.

Pratiwi, K. S. (2020). Analisis Du Pont Pada Perusahaan Pt Garuda Indonesia ( Persero ) Tbk 2015-2018. Jurnal Ekonomi Dan Bisnis.

Primadhany, E. F. (2018). Tinjauan Terhadap Tanggung Jawab Badan Pengelola Keuangan Haji (Bpkh) Dalam Melakukan Penempatan Dan/Atau Investasi Keuangan Haji. Jurisdictie, 8(2), 125. Https://Doi.Org/10.18860/J.V8i2.4447

Rahman, T. Etall. (2018). Kajian Akademik Pengelolaan Keuangan Dana Haji Ditinjau Dari Optimal Portofolio Investasi (Risk-Return Analysis) Dalam Menyongsong Visi Saudi 2030. Badan Pengelola Keuangan Haji, 2, 6-11.

Rolanda, I. (2014). Analisis Portofolio Optimal : Pendekatan Mean Variance ( Studi Kasus Pada Dana Pensiun Lembaga Keuanganmuamalat ). 201217.

Safelia, N. (2012). Konsep Dasar Keputusan Investasi Dan Portfolio Nela Safelia Staff Pengajar Fakultas Ekonomi Universitas Jambi Abstrak. Mankeu, 1(3).

Salatalohy, H. (2019). Pengaruh Inflasi Dan Bi Rate Terhadap Imbal Hasil Penyaluran Investasi Dana Haji Pada Sukuk Dana Haji Indonesia. Kordinat Uin, Xviii.

Sarwat, A. (2011). Seri Fiqih Kehidupan (6): Haji. Jakarta Selatan: Du Publishing.

Satiti, N. R. (2009). Optimalisasi Portofolio Investasi Dana Pensiun Universitas Muhammadiyah Malang. Jurnal Manajemen Bisnis, 3 No. 1(April), 73-84.

Setiawan, H., Siregar, H., \& Anggraeni, L. (2015). Optimalisasi Kinerja Portofolio Investasi (Studi Kasus Pada Dana Pensiun Pertamina). Jurnal Aplikasi Manajemen (Jam), 13 No.4(Desember), 557-565.

Sharpe, W. (1964). Capital Asset Prices: A Theory Of Market Equilibrium Under Conditions Of Risk* William. The Journal Of Finance, Xix, 425442.

Sharpe, W. F. (2005). Investasi (1st Ed.). Jakarta: Pt Indeks Kelompok Gramedia.

Supomo, D. N. (2016). Metodologi Penelitian Bisnis. Yogyakarta. 
27 | Arif Setiawan, Hendro Wibowo, Mustafa Kamal : Analysis of 0ptimization Model of Haji Financial Investment Portofolio in BPKH (Haji Financial Management Agency of the Republic of Indonesia)

Sugiyono, P. D. (2013). Cara Mudah Menyusun Skripsi, Tesis, Dan Disertasi $($ Std). Yogyakarta: Alfabeta.

Syaifuddin, D. (2008). Manajemen Keu. In Journal Of Chemical Information And Modeling (Vol. Https://Doi.Org/10.1017/Cbo9781107415324.004

Tandelilin, E. (2010). Dasar-Dasar Manajemen Investasi. In Manajemen Investasi (P. 34).

Triharjono, S. (2014). Single Index Model Sebagai Alat Analisis Optimalisasi Portofolio Investasi Saham (Studi Kasus Pada Kelompok Saham Lq-45 Di Bei Tahun 2009-2011). Jurnal Ilmu Manajemen Dan Bisnis, 5(1), 112. Https://Doi.Org/10.17509/Jimb.V5i1.1012

Wibowo, H., \& Salatalohy, H. (2018). Pengaruh Inflasi Dan Bi Rate Terhadap Imbal Hasil Penyaluran Investasi Dana Haji Pada Sukuk Dana Haji Indonesia. Jurnal Koordinat, 1(4), 53.

Witjaksono, B. (2019). Insight Bpkh. Pp. 3-5.

Zivot, E. (2016). Introduction To Computational Finance And Financial Econometrics With R. In Faculty.Washington.Edu (Pp. 1-54). 
Jurnal Ekonomi dan Perbankan Syariah

Vol. 8. No.1, April 2020: 5-27 ISSN (printed): 2355-1755 | ISSN (online): 2579-6437 